\title{
The effects of carbohydrate-enriched meals on glucose turnover and metabolic clearance rates of glucose in Type 2 diabetic patients
}

\author{
K. Osei, J. M. Falko, P. G. Fields, B. Bossetti and T. M.O'Dorisio \\ The Ohio State University College of Medicine, Division of Endocrinology and Metabolism, Columbus, Ohio, USA
}

\begin{abstract}
Summary. The addition of fructose to natural meals elicits lower serum glucose and immunoreactive insulin responses when compared with that of sucrose and starch meals. Differences in rates of splanchnic glucose appearance and peripheral glucose disposal may be partly responsible. To evaluate the role of both parameters after different carbohydrate-enriched meals, we measured the arterialized venous blood glucose, immunoreactive insulin and gastric inhibitory polypeptide concentrations in seven Type 2 diabetic patients after ingestion of isocaloric test meals. Measurements were made in a random manner on three separate occasions. Fructose, sucrose, and bread supplementation constituted $68 \%$ of the total carbohydrate content of each meal. Rates of total glucose appearance, glucose utilization and metabolic clearance rates of glucose were determined by the $\mathrm{D}^{3}$-H-3glucose prime-continuous infusion technique. The mean fasting glucose levels were similar in the three groups. Mean peak glucose concentrations and integrated incremental areas were significantly lower $(p<0.02)$ after the fructose-enriched meals compared with that of either sucrose or bread. The basal arterialized venous blood glucose levels were similar in all three groups. The mean incremental integrated arterialized venous blood glucose area was significantly lower in the fructose group when compared with the
\end{abstract}

sucrose $(p<0.05)$ and bread $(p<0.02)$ groups. The mean fasting gastric inhibitory polypeptide levels were similar in the three groups. However, the mean incremental integrated gastric inhibitory polypeptide areas were significantly lower in the fructose group compared with the sucrose and bread groups ( $p<0.01$ and $p<0.05$ respectively). Basal hepatic glucose outputs were not significantly different in the three groups. After each test meal ingestion, the rate of total glucose appearance was lowest for the fructose group, intermediate for the bread group and highest for the sucrose group. However, the metabolic clearance rate did not change from the baseline despite variable arterialized venous blood glucose responses after each test meal. We conclude that the differences in glycaemic responses after carbohydrate-enriched meals cannot be ascribed solely to differences in peripheral glucose disposal in Type 2 diabetic patients. Rather, the rates of total splanchnic glucose output appear to determine the ultimate glycaemic responses after different carbohydrate-enriched meals in Type 2 diabetic patients.

Key words. Glucose, insulin, Type 2 diabetes mellitus, glucose appearance $(\mathrm{RA})$, metabolic clearance rate (MCR).
Recent reports indicate that both high and complex carbohydrate $(\mathrm{CHO})$ meals improve glycaemic control in some diabetic patients $(1,2-6)$. In this regard, the Committee of Food and Nutrition of The American Diabetic Association (ADA) has recommended that $50-60 \%$ of the total energy intake of Type 1 (insulin-dependent) and Type 2 (non-insulin-dependent) diabetic patients be derived from complex CHO [1]. Even though simple sugars have been specifically discouraged in the diet of diabetic patients, some investigators have recommended fructose supplements in order to improve dietary compliance in diabetic patients [7,8]. In support of their findings, it has been shown that fructose elicits lower blood glucose levels while sucrose and potato elicit higher but similar glycaemic responses [7-15]. In addition, the physical form of the carbohydrate may influence the glycaemic and hormonal responses after oral ingestion [15-18].

Invasive hepatic vein catherization techniques have been used to study glucose turnover rates after the ingestion of different carbohydrates [19]. The use of noninvasive isotope techniques to study postmeal glucose turnover rates and metabolism have rarely been employed in man [20,21]. In most previous studies, these carbohydrates were given as either oral formula drinks or by intraduodenal and intravenous infusions, which are unnatural for diabetic patients [20,21]. Only a few studies have employed natural food plans similar to 
Table 1. Clinical characteristics of Type 2 diabetic patients

\begin{tabular}{lllllllllll}
\hline Name & $\begin{array}{l}\text { Age } \\
(\mathrm{yrs})\end{array}$ & Sex & $\begin{array}{l}\text { Ideal body } \\
\text { weight } \\
(\%)\end{array}$ & $\begin{array}{l}\text { Surface } \\
\text { area } \\
\left(\mathrm{m}^{2}\right)\end{array}$ & $\begin{array}{l}\text { Body mass } \\
\text { index } \\
\left(\mathrm{kg} / \mathrm{m}^{2}\right)\end{array}$ & $\begin{array}{l}\text { Duration of } \\
\text { diabetes } \\
(\mathrm{yr})\end{array}$ & $\begin{array}{l}\text { Drug } \\
\text { therapy }\end{array}$ & $\begin{array}{l}\text { Daily } \\
\text { dose }\end{array}$ & $\begin{array}{l}\text { Fasting serum } \\
\text { glucose } \\
(\mathrm{mg} / \mathrm{dl})\end{array}$ & $\begin{array}{l}\text { Glycosylated } \\
\text { hemoglobin } \\
(\%)\end{array}$ \\
\hline G.H. & 45 & Female & 140 & 1.78 & 35 & 6 & Tolinase & $500 \mathrm{mg}$ & 213 & 13 \\
W.W. & 55 & Female & 133 & 1.57 & 33 & 9 & Tolinase & $500 \mathrm{mg}$ & 210 & 11.75 \\
R.R. & 51 & Male & 120 & 1.68 & 28 & 1 & Tolinase & $250 \mathrm{mg}$ & 202 & 168 \\
C.B. & 55 & Male & 114 & 1.55 & 25 & 1 & Tolinase & $500 \mathrm{mg}$ & 168 & 9.68 \\
V.B. & 39 & Male & 127 & 1.70 & 28 & 0.5 & Diabenese & $500 \mathrm{mg}$ & 217 & 11.56 \\
E.L. & 28 & Female & 176 & 1.86 & 39 & - & - & - & 252 & 12.28 \\
H.H. & 58 & Male & 120 & 1.82 & 29 & 14 & Insulin & 58 units & 186 & 9.98 \\
\hline
\end{tabular}

Table 2. Composition of carbohydrate-enriched $500 \mathrm{kcal}$ breakfast test meals

\begin{tabular}{lccc}
\hline Food items & I & II & III \\
\hline & & grams & \\
Cream of Wheat & 25.40 & 25.40 & 25.40 \\
Scrambled egg & 100.00 & 100.00 & 100.00 \\
Margarine & 10.00 & 10.00 & 6.60 \\
Composition of meal & & & \\
$\quad$ Carbohydrate & $63(50 \%)$ & $63(50 \%)$ & $63(50 \%)$ \\
$\quad$ Complex & $20(16 \%)$ & $20(16 \%)$ & $42(34 \%)^{\mathrm{c}}$ \\
$\quad$ Simple & $42(34 \%)^{\mathrm{a}}$ & $42(34 \%)^{\mathrm{b}}$ & $20(17 \%)$ \\
$\quad$ Protein & $16(12 \%)$ & $16(12 \%)$ & $20.2(16 \%)$ \\
$\quad$ Fat & $22(39 \%)$ & $22(39 \%)$ & $19(33 \%)$ \\
\hline
\end{tabular}

$\mathrm{I}=$ Fructose-enriched meals; $I \mathrm{I}=$ Sucrose-enriched meals; III = Bread-enriched meals.

${ }^{a}$ Crystalline fructose $;{ }^{b}$ crystalline sucrose; ${ }^{c}$ pita bread.

Numbers in parenthesis indicate the percent calories of the $500 \mathrm{kcal}$ breakfast meal

usual American meals to elucidate the contribution of different carbohydrates to total splanchnic glucose output (TSGO) and glucose turnover. This is important since both the quality and quantity of the carbohydrate meal determine ultimate serum glycaemic responses and perhaps patient compliance [13-16]. Jenkins et al. [13] have determined glycaemic indices of several food items as an aid for food selection in the diabetic population. However, since each food item was given in isolation, it is difficult to extrapolate their findings to natural mixed meals.

This study was therefore designed to evaluate glucose turnover rates using the $D^{3}-\mathrm{H} \cdot 3$ glucose infusion technique after ingestion of breakfast mixed meals enriched with either fructose, sucrose, or bread in Type 2 diabetic patients. The aim of the study was to determine whether differences in glycaemic responses after carbohydrate-enriched meals were due to differences in peripheral glucose disposal as assessed by the metabolic clearance rates of glucose or by the total splanchnic glucose output in these patients.

\section{Subjects and methods}

Seven Type 2 diabetic patients ( 3 females and 4 males) were studied. The clinical characteristics of the patients are shown in Table 1. All except one patient were on oral hypoglycaemic agents or insulin and continued the same dose throughout the study period. None of the patients had liver or renal disease or clinical evidence of visceral autonomic neuropathy. Dietary recalls were done by a registered dietician to ensure that the patients were on an isocaloric weight-maintaining diet comprising $45 \%$ carbohydrate, $40 \%$ fat and $15 \%$ protein. Patients were instructed to continue the same diet and exercise program during the study period. No significant weight changes occurred in any patient during the 3 visits for the study.

Informed written consent approved by both The Ohio State University Human Research and Radiation Safety Committees was obtained from each patient.

\section{Study design}

Table 2 shows the composition of sucrose-, fructose-, and starch-enriched test meals. The sucrose, fructose, or starch supplementation constituted $50 \%$ of the total caloric content (500 kcal) and $68 \%$ of the total carbohydrate content of each meal. Sucrose or fructose supplementation was added to the natural basic meal in a crystalline form. The starch used in our study was pita bread. Each breakfast meal was given in a randomized manner on 3 occasions separated by at least 7 days. The food was freshly prepared on the morning of the study by the metabolic kitchen staff of the Clinical Research Centre. Carbohydrate, protein, and fat contents of the 3 meals were calculated from established Bowes and Church's Food Values published previously [22], and, where applicable, from the manufacturers' label on the containers. Chemical analysis of the different food items was not performed.

Patients were admitted to the Centre at $08: 00 \mathrm{~h}$ on the day of study after a 10-12 h overnight fast. A 19-gauge scalp vein needle was inserted in a retrograde manner in a dorsal vein of the contralateral hand and kept patent with $0.9 \% \mathrm{~N}$ saline. The hand was then kept in a thermoregulated heat box with a temperature of $70 \pm 2{ }^{\circ} \mathrm{C}$ for arterialization of the venous blood and sampling. A second 19-gauge scalp vein needle was inserted in a forearm vein in an antegrade fashion. A prime-continuous tracer infusion of sterile, pyrogen-free $\mathrm{D}^{3}-\mathrm{H}-3 \mathrm{glu}$ cose (specific activity $10.8 \mathrm{Ci} / \mathrm{mmol}$, New England Nuclear, Boston, MA, USA) in $0.9 \% \mathrm{~N}$ saline was used. A priming dose of $25 \mu \mathrm{Ci} / \mathrm{min}$ was given followed by a continuous infusion of $0.25 \mu \mathrm{Ci} / \mathrm{min}$ throughout the entire study period of $330 \mathrm{~min}$. The prime dose and tracer infusion rates were adjusted according to the fasting serum glucose levels. After at least $120 \mathrm{~min}$ of isotope infusion, two blood samples were obtained at $20 \mathrm{~min}$ intervals for estimation of specific glucose activity (SA), serum glucose, arterialized venous glucose (IRI) and gastric inhibitory polypeptide (GIP). The means of these 2 values were used to represent the baseline values. Patients then ingested the test meal within $20 \mathrm{~min}$. The first bite was considered the commencement of the meal tolerance test. Blood samples were obtained at $20 \mathrm{~min}$ intervals for the next $180 \mathrm{~min}$. Samples were immediately centrifuged at $4{ }^{\circ} \mathrm{C}$, then sera were collected and frozen at $-20^{\circ} \mathrm{C}$ until assayed. Urine specimens were collected during the 180 min test period for glucose measurement.

\section{Chemical analyses}

Serum and urine glucose were determined by the glucose oxidase method using the Beckman autoanalyzer (Beckman Instruments, 
Table 3. Mean serum glucose and insulin levels, rates of glucose appearance (RA), glucose utilization (RU), and metabolic clearance rates of glucose (MCR) after ingestion of fructose-, sucrose-, and breadenriched test meals in Type 2 diabetic patients

\begin{tabular}{|c|c|c|c|c|c|c|c|c|c|c|}
\hline & \multicolumn{10}{|l|}{ Time (min) } \\
\hline & 0 & 20 & 40 & 60 & 80 & 100 & 120 & 140 & 160 & 180 \\
\hline & Glucose (m & $g / d i)$ & & & & & & & & \\
\hline Fructose & $205 \pm 22$ & $201 \pm 24$ & $227 \pm 20$ & $245 \pm 25$ & $246 \pm 28$ & $244 \pm 27$ & $237 \pm 26$ & $226 \pm 26$ & $214 \pm 27$ & $207 \pm 29$ \\
\hline Sucrose & $191 \pm 17$ & $232 \pm 16$ & $254 \pm 15$ & $274 \pm 16$ & $273 \pm 20^{\mathrm{a}}$ & $265 \pm 20^{\mathrm{b}}$ & $253 \pm 19^{\mathrm{a}}$ & $244 \pm 27^{\mathrm{a}}$ & $230 \pm 18$ & $226 \pm 18$ \\
\hline Bread & $207 \pm 16$ & $222 \pm 21$ & $252 \pm 17$ & $255 \pm 17$ & $271 \pm 25^{b}$ & $266 \pm 27^{b}$ & $262 \pm 28^{b}$ & $254 \pm 27^{b}$ & $243 \pm 27^{b}$ & $239 \pm 24^{\mathrm{b}}$ \\
\hline $\begin{array}{l}\text { Fructose } \\
\text { Sucrose } \\
\text { Bread }\end{array}$ & $\begin{array}{r}\text { Insulin }(\mu \mathrm{U} \\
13.2 \pm 3.3 \\
14.8 \pm 4.9 \\
16.9 \pm 4.5\end{array}$ & $\begin{array}{l}(\mathrm{ml}) \\
17.4 \pm 3.6 \\
25.5 \pm 9.0 \\
25.4 \pm 5.0\end{array}$ & $\begin{array}{l}17.2 \pm 2.0 \\
33.3 \pm 5.9 \\
42.6 \pm 11.7\end{array}$ & $\begin{array}{l}32.1 \pm 6.4 \\
36.6 \pm 7.3 \\
46.6 \pm 9.6\end{array}$ & $\begin{array}{l}29.4 \pm 6.5 \\
35.6 \pm 4.4 \\
36.5 \pm 4.9\end{array}$ & $\begin{array}{l}29.6 \pm 5.4 \\
37.6 \pm 6.1 \\
43.5 \pm 7.4\end{array}$ & $\begin{array}{l}26.2 \pm 4.3 \\
31.1 \pm 5.9 \\
39.0 \pm 10.4\end{array}$ & $\begin{array}{l}23.3 \pm 3.5 \\
26.6 \pm 8.0 \\
35.4 \pm 8.9\end{array}$ & $\begin{array}{l}21.7 \pm 4.2 \\
25.5 \pm 6.5 \\
34.0 \pm 8.7\end{array}$ & $\begin{array}{l}18.0 \pm 2.9 \\
27.0 \pm 6.5 \\
31.2 \pm 8.2\end{array}$ \\
\hline $\begin{array}{l}\text { Fructose } \\
\text { Sucrose } \\
\text { Bread }\end{array}$ & $\begin{array}{l}\text { Rates of } \mathrm{gl} \\
222 \pm 60 \\
203 \pm 63 \\
195 \pm 55\end{array}$ & $\begin{array}{ll}221 & \pm 61 \\
209 & \pm 63 \\
195 & \pm 66\end{array}$ & $\begin{array}{cc}\text { ance }(\mathrm{RA})(\mathrm{n} \\
237 & \pm 69 \\
243 & \pm 68 \\
214 & \pm 59\end{array}$ & $\begin{array}{ll}259 & \pm 75 \\
263 & \pm 66 \\
246 & \pm 64\end{array}$ & $\begin{array}{l}262 \pm 76 \\
270 \pm 70 \\
244 \pm 64\end{array}$ & $\begin{array}{l}257 \pm 69 \\
268 \pm 63 \\
241 \pm 64\end{array}$ & $\begin{array}{ll}246 & \pm 65 \\
250 & \pm 64 \\
228 & \pm 67\end{array}$ & $\begin{array}{ll}225 & \pm 56 \\
230 & \pm 55 \\
217 & \pm 59\end{array}$ & $\begin{array}{ll}207 & \pm 46 \\
215 & \pm 44 \\
208 & \pm 46\end{array}$ & $\begin{array}{ll}206 & \pm 55 \\
230 & \pm 68 \\
211 & \pm 57\end{array}$ \\
\hline $\begin{array}{l}\text { Fructose } \\
\text { Sucrose } \\
\text { Bread }\end{array}$ & $\begin{array}{l}\text { Rates of gl } \\
222 \pm 59 \\
203 \pm 63 \\
199 \pm 68\end{array}$ & $\begin{array}{ll}\text { ucose utilizat } \\
218 & \pm 58 \\
205 & \pm 60 \\
195 & \pm 67\end{array}$ & $\begin{array}{ll}\text { on }(\mathrm{RU})(\mathrm{m} \\
224 & \pm 58 \\
231 & \pm 56 \\
209 & \pm 58\end{array}$ & $\begin{array}{ll}/ \min ) & \\
246 & \pm 65 \\
246 & \pm 64 \\
213 & \pm 58\end{array}$ & $\begin{array}{l}261 \pm 75 \\
270 \pm 72 \\
250 \pm 77\end{array}$ & $\begin{array}{ll}262 & \pm 74 \\
273 & \pm 71 \\
239 & \pm 63\end{array}$ & $\begin{array}{ll}242 & \pm 63 \\
250 & \pm 63 \\
226 & \pm 65\end{array}$ & $\begin{array}{ll}222 & \pm 53 \\
230 & \pm 55 \\
214 & \pm 56\end{array}$ & $\begin{array}{ll}204 & \pm 44 \\
213 & \pm 55 \\
217 & \pm 55\end{array}$ & $\begin{array}{ll}211 & \pm 54 \\
232 & \pm 66 \\
204 & \pm 55\end{array}$ \\
\hline $\begin{array}{l}\text { Fructose } \\
\text { Sucrose } \\
\text { Bread }\end{array}$ & $\begin{array}{c}\text { Metabolic c } \\
59 \pm 10 \\
57 \pm 10 \\
49 \pm 13\end{array}$ & $\begin{array}{l}\text { learance rates } \\
59 \pm 9 \\
48 \pm 10 \\
45 \pm 12\end{array}$ & $\begin{array}{c}\text { (MCR) }(\mathrm{ml} \\
52 \pm 8 \\
48 \pm 8 \\
42 \pm 10\end{array}$ & $\begin{array}{c}\left./ \mathrm{m}^{2} \cdot \min \right) \\
54 \pm 9 \\
50 \pm 9 \\
49 \pm 10\end{array}$ & $\begin{array}{ll}63 & \pm 10 \\
54 & \pm 8 \\
48 & \pm 10\end{array}$ & $\begin{array}{l}57 \pm 9 \\
55 \pm 7 \\
47 \pm 9\end{array}$ & $\begin{array}{l}53 \pm 10 \\
53 \pm 7 \\
45 \pm 9\end{array}$ & $\begin{array}{l}52 \pm 9 \\
52 \pm 6 \\
45 \pm 8\end{array}$ & $\begin{array}{l}51 \pm 8 \\
51 \pm 4 \\
46 \pm 6\end{array}$ & $\begin{array}{l}52 \pm 8 \\
50 \pm 5 \\
46 \pm 8\end{array}$ \\
\hline
\end{tabular}

${ }^{\mathrm{a}} p<0.05 ;{ }^{\mathrm{b}} p<0.02$ versus fructose

Table 4. Mean integrated incremental serum glucose, insulin and GIP and rates of glucose appearance (RA) and utilization (RU) after sucrose-, bread-, and fructose-enriched mixed meal in Type 2 diabetic patients

\begin{tabular}{|c|c|c|c|c|c|}
\hline $\begin{array}{l}\text { Carbohydrate } \\
\text { supplement }\end{array}$ & $\begin{array}{l}\text { Glucose } \\
\mathrm{mg} \cdot \mathrm{dl}^{-1} \cdot \min ^{-1}\end{array}$ & $\begin{array}{l}\text { Insulin } \\
\mu \mathrm{U} \cdot \mathrm{mI}^{-1} \cdot \min ^{-1}\end{array}$ & $\begin{array}{l}\text { Gastric inhibitory } \\
\text { polypeptide } \\
\mathrm{pg} \cdot \mathrm{ml}^{-1} \cdot \min ^{-1}\end{array}$ & $\begin{array}{l}\text { Rates of glucose } \\
\text { appearance (RA) } \\
\text { mg }\end{array}$ & $\begin{array}{l}\text { Rates of glucose } \\
\text { utilization (RU) } \\
\mathrm{mg}\end{array}$ \\
\hline Sucrose & $14,460 \pm 1,560^{\mathrm{b}}$ & $3,162 \pm 409^{d}$ & $152,388 \pm 31,900^{b}$ & $11,080 \pm 1,386^{b}$ & $10,520 \pm 940^{b}$ \\
\hline Bread & $12,160 \pm 1,780^{c}$ & $3,770 \pm 768^{c}$ & $127,800 \pm 30,566^{\mathrm{a}}$ & $8,880 \pm 2,120^{c}$ & $7,420 \pm 2,000^{\mathrm{C}}$ \\
\hline Fructose & $8,140 \pm 1,592$ & $2,195 \pm 180$ & $79,998 \pm 25,860$ & $6,940 \pm 1,973$ & $6,280 \pm 1,275$ \\
\hline
\end{tabular}

Values are mean \pm SEM

${ }^{a} p<0.05$ Bread versus fructose

$p<0.02$ Sucrose versus fructose

c $p<0.02$ Bread versus fructose

d $p<0.05$ Sucrose versus fructose

No significant differences existed between any of these parameters when the sucrose-enriched meal was compared with the bread-enriched meal

Fullerton, CA, USA). $\mathrm{HbA}_{1}$ was determined by the column chromatographic technique (Isolabs, Akron, OH, USA). Serum immunoreactive insulin levels were determined by the double antibody RIA technique of Morgan and Lazarow [23] using a commercial kit (Corning Medical, Medfield, MA, USA). Standard pure porcine insulin was purchased from Eli-Lilly Company (Indianapolis, IN, USA). The sensitivity of the assay was less than $2.5 \mu \mathrm{U} / \mathrm{ml}$ serum. The inter- and intra-assay coefficients of variation were $14 \%$ and $6 \%$ respectively. GIP levels were determined by RIA technique using a GIP standard (Type EG III 6/19/80) (Quadralogic Technologies, Inc., Vancouver, BC, Canada). The GIP antibody was provided by Dr. V Marks of the University of Surrey, England. Rabbit anti-porcine antibody was used in a final dilution of $1: 30,000$. The sensitivity of the assay was $225 \mathrm{pg} / \mathrm{ml}$ serum. The intra- and inter-assay coefficients of variation were $5 \%$ and $15 \%$ respectively. There was no cross-reactivity between GIP, glucagon, vasoactive intestinal polypeptide (VIP) or bombesin in our assay.

Glucose turnover rates were determined by the single isotope dilution technique using $\mathrm{D}^{3}-\mathrm{H}-3$ glucose as previously described [24-26]. In brief, duplicate plasma samples of $0.4 \mathrm{ml}$ were added to $0.4 \mathrm{ml}$ of chilled $3 \mathrm{~mol} / 1$ perchloric acid to deproteinize plasma proteins. After $20 \mathrm{~min}$ of centrifugation at $4^{\circ} \mathrm{C}$ and $3,000 \times \mathrm{g}, 0.5 \mathrm{ml}$ of the supernatant was aspirated, neutralized with $\mathrm{NaHCO}_{3}$ and placed in scintillation vials. The samples were then evaporated to dryness (to eliminate tritiated water) and reconstituted with $0.5 \mathrm{ml}$ deionized distilled water. Four and one-half $\mathrm{ml}$ of scintillation liquid (Acquasol) was added to each vial and then counted for $10 \mathrm{~min}$ in a liquid scintillation spectrometer (Packard Instruments, Downer Grove, IL, USA) using an internal quench. The specific activity of glucose was calculated by dividing the total radioactive counts per min (after correction for dilution) by the ambient glucose concentration. The flow rate $(F)$ of the tracer infusion was determined by the activity in a given volume of the infusate per unit time.

In the steady post-absorptive state, the glucose entering the circulation is derived predominantly from the liver. Thus the total rate of glucose appearance (RA) in the steady state is the same as the basal hepatic glucose output (HGO). In the steady state the total RA also equals the $R D$ (rate of glucose disappearance), $R A=R D=F / S A$, where SA is the specific glucose activity at the baseline. After oral $\mathrm{CHO}$ meal ingestion, glucose begins to enter the circulation, thus dis- 
turbing the steady state. The Steele's equation of unsteady state kinetics [27] was used to calculate the glucose flux rates as follows:

$\mathrm{RA}=[\mathrm{F}-\mathrm{p} . \mathrm{V} . \mathrm{G} . \mathrm{a} / \mathrm{t}] . \mathrm{l} / \mathrm{a}$

$R D=R A-$ p.V. G. $1 / t$

where $\mathrm{RA}=$ rates of glucose appearance, $\mathrm{RD}=$ rates of glucose disappearance, $G=$ averages of glucose concentration $(\mathrm{mg} / \mathrm{ml}), a=$ glucose specific activity $(\mathrm{cpm} / \mathrm{min})$ during the interval $t=20 \mathrm{~min} ; G$ and $\mathrm{a}=$ changes in the glucose concentration and specific activity respectively during the $t=20 \mathrm{~min} ; \mathrm{F}=$ tracer dose infused $(\mathrm{cpm} / \mathrm{min}$ ), $\mathrm{V}=$ apparent distribution space of glucose, (taken as $200 \mathrm{ml} / \mathrm{kg}$ ) and $p=0.65$, pool fraction of glucose space $[25,27,28]$.

In the presence of glycosuria, $R D=R U+R E$, where $R U$ is the rate of glucose uptake by the tissues and RE is the rate of urinary glucose excretion. The metabolic clearance rate of glucose (MCR) was calculated by dividing the RU by the ambient serum glucose concentration $[29,30]$.

\section{Statistical analysis}

Results are expressed as the mean \pm SEM. Because of variability in the fasting glucose, insulin, GIP, RA and RU values, we analyzed both the absolute as well as the postprandial incremental values. Individual increments were computed by subtracting basal values from the respective values at $20 \mathrm{~min}$ intervals. Incremental integrated areas were computed by the trapezoidal rule using a Hewlett-Packard Programmable Computer (Model \#9100B). Statistical analyses were performed using two-tailed Student's paired and unpaired t-tests and ANOVA where appropriate, $p<0.05$ considered statistically significant.

\section{Results}

Table 3 shows the mean baseline and postprandial serum glucose, insulin, RA, RU and MCR values after the ingestion of fructose-, sucrose-, and bread-enriched test meals. Mean fasting serum glucose levels were similar in all 3 groups (fructose, $205 \pm 22 \mathrm{mg} / \mathrm{dl}$; sucrose, $191 \pm 17 \mathrm{mg} / \mathrm{dl}$; bread, $207 \pm 16 \mathrm{mg} / \mathrm{dl}$ ). After the fructose-enriched meal, mean serum glucose responses were lower compared with that of either the sucrose- or bread-enriched meals. Mean peak glucose levels occurred at $60 \mathrm{~min}$ in all 3 groups, but values were significantly $(p<0.02)$ lower after the fructose- compared with either sucrose- or starch-enriched meals. Both sucrose- and bread-enriched meals elicited identical glucose peaks. At 160 and $180 \mathrm{~min}$, mean serum glucose levels were not statistically significant between the fructose and sucrose groups. However, the bread group maintained significantly $(p<0.02)$ higher glucose levels compared with the fructose group at both 160 and $180 \mathrm{~min}$. Mean incremental integrated glucose areas were significantly lower $(p<0.02)$ in the fructose group compared with both sucrose and bread groups (Table 4). Mean incremental integrated glucose areas were not different between the sucrose and bread groups.

The mean fasting serum IRI levels were similar in the 3 groups (fructose: $13.2 \pm 3.3$; sucrose $14.8 \pm 4.9$; bread $16.9 \pm 4.5 \mu \mathrm{U} / \mathrm{ml}$ ). However, the postprandial responses were varied (Table 3 ). The mean incremental integrated IRI areas were significantly lower in the fructose group compared with the bread group (2195 \pm 180 versus $3770 \pm 768 \mu \mathrm{U} \cdot \mathrm{ml}^{-1} \cdot \mathrm{min}^{-1}, p<0.02$, Table 4) and the sucrose group (2195 \pm 180 versus $3162 \pm 409$, $p<0.05$, Table 4). Mean integrated incremental IRI areas were not statistically significant between the sucrose and bread groups.

Mean fasting serum GIP levels were not different in the 3 groups (fructose: $533 \pm 144$, sucrose: $538 \pm 177$, bread: $477 \pm 77 \mathrm{pg} / \mathrm{ml}$ ). After test meal ingestion, mean GIP levels increased significantly $(p<0.02)$ at $20 \mathrm{~min}$ in the sucrose group but not in the bread and fructose groups (sucrose, $1,200 \pm 190$ versus bread, $750 \pm 69$ and fructose, $619 \pm 123 \mathrm{pg} / \mathrm{ml}, p<0.05$ ). At all other times studied, mean GIP levels were not statistically significant between the 3 groups. However, mean integrated incremental GIP areas were significantly higher in both the sucrose $(p<0.01)$ and bread $(p<0.05)$ groups compared with the fructose group (Table 4 ).

The mean basal hepatic glucose outputs (RA at time $=0 \mathrm{~min}$ ) were $222 \pm 60,203 \pm 63$, and $195 \pm$ $55 \mathrm{mg} / \mathrm{min}$ for the fructose, sucrose, and bread groups respectively (Table 3 ). These values were not statistically significant. After oral meal ingestion, mean integrated incremental RA values were highest in the sucrose group, intermediate in the bread group, and least in the fructose group ( $p<0.05$ fructose versus bread and sucrose, Table 4). There was also a similar trend for the RU in all 3 groups (Tables 3,4). The mean MCR did not change from baseline values after the test meal ingestion in any of the 3 groups throughout the study period (Table 3).

Mean urinary glucose excretion during the $180 \mathrm{~min}$ study period were $2.5 \pm 1.6,2.1 \pm 1.1$ and $5.5 \pm 2.5 \mathrm{~g}$ for fructose, sucrose, and bread groups respectively. These values were not statistically significant.

\section{Discussion}

Recent attention has focused on complex $\mathrm{CHO}$ as a means of improving glycaemic control in diabetic patients $[1-6,31,32]$. There are still concerns that simple sugars may be rapidly absorbed and may cause wide glucose excursions. Indeed, most diabetologists, general practitioners and dieticians have accepted this notion for several decades. In contrast, other investigators have demonstrated that simple sugars such as glucose and sucrose given either as a meal or incorporated in natural meals elicit glycaemic responses similar to that of potato and wheat starch $[15,18]$. The simple sugar, fructose, given alone or incorporated in natural meals resulted in lower glycaemic responses consistently in all these studies. In this light, Pekonen et al. [8] and other investigators [33] have suggested the use of fructose as a natural sweetener in the diets for normolipidaemic Type 1 and 2 diabetic patients.

Recently Jenkins et al. [13] have derived glycaemic indices for various food items which have been advocated as a guide for food selection for diabetic patients. 
However, the applicability of such indices in a mixed meal remains controversial. Furthermore, glucose turnover rates were not evaluated in any of the previous studies after ingesting carbohydrate-enriched meals. Thus, whether increased rates of total splanchnic glucose appearance (RA) or decreased peripheral utilization (RU) of glucose predominates in the determination of overall glucose responses after different $\mathrm{CHO}$ meal ingestion in diabetic patients is unclear.

Our study showed that mean serum glucose responses after fructose-enriched meals were significantly lower compared with sucrose- and bread-enriched meals, and agreed with those of Bantle et al. [15]. Although the specific absorption rates of glucose after each CHO meal ingestion was not determined with a second oral isotope as suggested by Radziuk et al. [20], and was not the purpose of our study, the similarities in the serum glucose levels and the total splanchnic glucose output (RA) after sucrose (disaccharide)- and pita bread (polysaccharide)-enriched meals indicate that probably enzymatic digestion and absorption are not the major limiting factors in the glucose responses following these two CHO-enriched meals $[34,35]$. This is in agreement with the previous observations by Dahlquist and Borgstrom [34] and Fogel and Gray [35], who demonstrated that after starch meals there is more than enough amylase present intraluminally to cause hydrolysis of starch with a hydrolytic capacity of $360 \mathrm{~g} / \mathrm{h}$. The available glucose moieties in the sucrose and starch meals were comparable in the present study. Our findings are also in agreement with those of Jenkins et al. [15], who found a lower "glycaemic index" after fructose compared with sucrose and starch ingestion.

The serum glucose concentrations as well as RA returned to the baseline values at the end of $180 \mathrm{~min}$ in the fructose group. In contrast, both sucrose- and bread-enriched meals elicited higher incremental RA and serum glucose responses even at $180 \mathrm{~min}$ above the baseline values, suggesting prolonged and continuous absorption of these $\mathrm{CHO}$ as glucose moieties in our diabetic patients. It should, however, be noted that endogenous hepatic glucose production (HGO) contributes to the total RA since basal HGO is suppressed by approximately $66 \%$ after oral glucose ingestion [20]. This was not specifically assessed in our study. Furthermore, the lower incremental RA and serum glucose responses after the fructose-enriched meal may be attributed to the limited conversion of absorbed fructose to glucose as well as the rapid metabolism of fructose into trioses in the liver [31]. Shoemaker et al. [36] reported that $50 \%$ of ingested fructose is converted to glucose by the gut and the rest metabolized by the liver in dogs. However, lower figures have been reported by Cook [19] and Atwell et al. [21]. It is also possible that fructose per se may suppress hepatic glucose output.

The unchanged MCR after each meal indicates that peripheral glucose disposal is unlikely to explain the differences in glycaemic responses after $\mathrm{CHO}$ meals.
We should note that the use of MCR as a true reflection of peripheral glucose disposal remains uncertain [29, 30]. Nevertheless, a recent review by Radziuk et al. [37] has indicated that MCR may reflect the irreversible glucose uptake by tissues and may therefore measure insulin sensitivity. Despite higher IRI levels after both bread- and sucrose-enriched meals compared with those of a fructose-enriched meal, the MCR did not change from the baseline values in any of the groups. Thus, it appears that the physiologic insulin concentrations achieved in the present study played a very small role in improving glucose disposal in the patients. This may be ascribed, in part, to the severity of the previously reported insulin insensitivity of peripheral tissues associated with Type 2 diabetic patients. Furthermore, Meyer et al. [38] have demonstrated that diabetic patients have defective glucose oxidative and storage capacities. Our data, together with these previous observations, support the concept of defective insulin- and non-insulin-mediated glucose transport and metabolism in Type 2 diabetic patients.

The augmented insulin secretion observed after sucrose- and bread-enriched meals could be attributed to the higher serum glucose levels and/or other enteric factors such as the insulinotropic action of GIP $[9,16$, 17]. In this respect, we have shown in previous studies that there are significant increases in GIP concentrations after oral ingestion of either sucrose- or bread-enriched meals when compared with fructose meals [9, 16].

Within the physiologic insulin concentrations achieved in our study, the effects of peripheral insulin concentration on glucose disposal as assessed by MCR appear to be minimal after ingestion of different carbohydrate-enriched meals. From our data, we conclude that a) total splanchnic glucose output significantly influences the overall glycaemic responses after acute ingestion of carbohydrate-enriched meals in diabetic patients, and b) dietary recommendations favoring restriction of simple sugars in favor of complex carbohydrates are not supported by our findings.

Acknowledgments. We wish to thank E. Robinson for her secretarial assistance; N. Latimer and T.Forcino for their technical assistance; the Clinical Research Center, GCRC-RR-34, NIH, Core Laboratory of Ohio State University, and Ohio State Roessler Scholarships Foundation. Supported in part by the Veterans Administration.

\section{References}

1. Committee on Food and Nutrition, American Diabetic Association (1983) Principles of nutrition and dietary recommendations for individuals with diabetes mellitus. J Am Diet Assoc 75: $517-530$

2. Brunzell JB, Lerner RL, Hazzard WR, Porte D, Bierman EL (1971) Improved glucose tolerance with high carbohydrate feeding in mild diabetes. N Engl J Med 294: 521-524

3. Simpson RW, Mann JI, Eaton J, Carter RD, Hockaday TDR (1979) High carbohydrate diets and insulin-dependent diabetes. Br Med J 2: 523-525 
4. Wenzier RL, Seeman A, Herrera MG, Assal JP, Soeldner JS, Gleason RE (1974) High and low carbohydrate diets in diabetes mellitus. Ann Int Med 80: 332-334

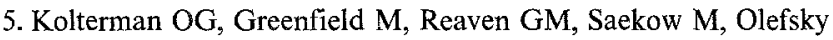
JM (1979) Effect of a high carbohydrate diet on insulin binding to adipocytes and on insulin action in vivo in man. Diabetes 28: $731-736$

6. Anderson JW (1977) Therapeutic effectiveness of high carbohydrate, high fiber, weight-maintaining diets in lean, insulin-treated diabetic men. Clin Res 25:619A

7. Anderson JW, Story L, Zettwoch N, Sieling B (1984) Longterm safety of fructose intake for diabetic men. Diabetes [Suppl 1]: 20 (Abstract)

8. Pekonen R, Aro A, Nikkila ES (1972) Metabolic effects of dietary fructose in insulin dependent diabetes of adults. Acta Med Scand 542: 187-193

9. Falko JM, Reynolds JC, O'Dorisio TM, Bosetti B, Cataland S (1982) The role of gastric inhibitory polypeptide in the augmented hyperinsulinemic response to oral sucrose. Diabetes Care 5: 379-385

10. Crapo PA, Kolterman OG, Olefsky JM (1980) Effects of oral fructose in normal, diabetic, and impaired glucose tolerance subjects. Diabetes Care 3: 575-581

11. Akgun S, Estel NH (1980) A comparison of carbohydrate metabolism after sucrose, sorbitol, and fructose meals in normal and diabetic subjects. Diabetes Care 3: 582-585

12. Akerblom HK, Siltanen I, Kallio AK (1972) Does dietary fructose affect the control of diabetes in children? Acta Med Scand 542 [Suppl] 195-202

13. Jenkins DJA, Wolever TMS, Taylor RH, Barker $H$, Fielden $H$ (1981) Glycemic index of foods; a physiological basis for carbohydrate exchange. Am J Clin Nutr 34:362-366

14. Gray GM, Ingelfinger FJ (1966) Intestinal absorption of sucrose in man. Interaction of hydrolysis and monosaccharide product absorption. J Clin Invest 45: 388-398

15. Bantle JP, Laine DC, Castle GW, Thomas JW (1983) Postprandial glucose and insulin responses to meals containing different carbohydrates in normal and diabetic subjects. $\mathrm{N}$ Engl J Med 309: 7-12

16. Collier G, O'Dea K (1982) Effects of physical form of carbohydrate on the postprandial glucose, insulin, and gastric inhibitory polypeptide responses in type II diabetes. Am J Clin Nutr 36: $10-14$

17. Crapo P, Reaven G, Olefsky J (1977) Postprandial plasma glucose and insulin responses to different complex carbohydrates. Diabetes $26: 1178-1183$

18. Crapo PA, Reaven G, Olefsky J (1976) Plasma glucose and insulin responses to orally administered simple and complex carbohydrates. Diabetes 25: 741-747

19. Cook GC (1970) Comparison of the absorption and metabolic products of sucrose and its monosaccharides in man. Clin Sci 38: 687-697

20. Radziuk J, Kemmer F, Morishima T, Berchtold P, Vranic M (1984) The effects of an alpha-glucoside hydrolase inhibitor on glycemia and the absorption of sucrose in man determined using a tracer method. Diabetes 33: 207-213

21. Atwell $\mathrm{E}$, Waterhouse C (1971) Glucose production from fructose. Diabetes 20: 193-199
22. Pennington JAJ, Church HR (1980) Bowes and Church's food values of portions commonly used, 13th edn. JB Lippincott, Philadelphia

23. Morgan CR, Lazarow A (1963) Immunoassay of insulin: two antibody system. Plasma insulin levels in normal, subdiabetic, and diabetic rats. Diabetes 12: 115-119

24. Dunn A, Katz J, Golden S (1976) Estimation of glucose turnover and recycling in rabbits using $\left({ }^{3} \mathrm{H},{ }^{14} \mathrm{C}\right)$ glucose labels. Am J Physiol 230: 159-162

25. Radziuk J, Norwich KH, Vranic M (1978) Experimental validation of measurement of glucose turnover in non-steady man. Am J Physiol E: 84-93

26. Rizza RA, Namdarino LJ, Gerich JE (1982) Effects of growth hormone on insulin action in man. Diabetes 31:663-669

27. Steele R, Wall J, DeBobo R, Altszuler N (1956) Measurement of size and turnover rate of body glucose pool by the isotope detection method. Am J Physiol 187: 15-24

28. Cowan JS, Hetenyi $G$ (1971) Glucoregulatory responses in normal and diabetic dogs recorded by a new tracer method. Metabolism $20: 360-372$

29. Verdonk CA, Rizza R, Gerich JE (1981) Effects of glucose concentration on glucose utilization and glucose clearance in normal man. Diabetes 30: 535-537

30. Best JD, Toborsky Jr J, Halter JB, Porte Jr D (1981) Glucose disposal is not proportional to plasma glucose levels in man. Diabetes $30: 847-850$

31. Richardson R (1929) High carbohydrate diets in diabetes mellitus. Am J Med 177: 426-430

32. Simple HL, McNutt KW (1974) Sugars in nutrition, 1st edn. Academic Press Inc, New York

33. Lenner RA (1976) Specially designed sweeteners and food for diabetics-a real need? Am J Clin Nutr 29: 726-733

34. Dahlquist A, Borgstrom B (1961) Digestion and absorption of dissaccharides in man. Biochem J 81: 411-418

35. Fogel MR, Gray GM (1973) Starch hydrolysis in man: an intraluminal process not requiring membrane digestion. J Appl Physiol 35: 63-67

36. Shoemaker WC, Yanof HM, Turk LN, Wilson H (1963) Glucose and fructose absorption in the unanesthetized dog. Gastroenterology 44: 654-663

37. Radziuk J, Lickley HLA (1985) The metabolic clearance of glucose: measurement and meaning. Diabetologia 28: 315-322

38. Meyer HU, Curchod B, Maeder E, Pahud P, Jequier E, Felber JP (1980) Modifications of glucose storage and oxidation in nonobese diabetics, measured by continuous indirect calorimetry. Diabetes $29: 752-756$

Received: 26 July 1985

and in revised form: 21 November 1985

K Osei, M.D.

N-1120 Doan Hall

The Ohio State University Hospitals

Columbus, Ohio 43210

USA 